\title{
Management immunodeficiency from preuniversity educational system
}

\author{
Lucica Cristea (Mitican), „Al. I. Cuza” University of Iasi, Romania
}

\begin{abstract}
The educational system finds itself again in the middle of crisis. The quantic progress that people all over the world are waiting for, seems to have met the totally unprepared educational system.

The globalization which has led to the increase of interdependence between economic and social systems makes this problem become a worldwide one and consequently, need a global solution. While the USA is looking for the ,perfect” teacher and the ,ideal" school, Europe is still trying to find methods for making the educational system more efficient. A contradiction rises therefore, between the role of school in society that is to form mature personalities, meant to contribute to the economic increase and, implicitly, to the development of society, and the decrease in importance of this activity to the level of any economic activity.

The text aims at verifying the hypothesis according to which management immunodeficiency from the preuniversity organizations has the most powerful influence on the increase of crisis within the educational system. How was school plagued by this immuodeficiency? To what extent did the management of these institutions contribute to this? Can the efficient decision constitute a remedy in this situation? These are questions that we ought to address to ourselves, even if we are not be able to find the best solution.
\end{abstract}

\section{Keywords}

immunodeficiency, educational management, globalization, efficient decision

\section{JEL Codes: I 20, I 21}

\section{The global crisis has School}

Education and learning is a component of culture and civilization history. Educational system, a community forward material and spiritual creation of the forerunners in the offspring.

The word education is of Latin origin, derived from the noun "educatio" which means growth, feeding, growing. Education is mandated to prepare the man as active element of social life ${ }^{1}$.

The education is to be conscious development of human potential and the formation of a mature personality type, which correspond to current and future conditions offered by the company. Education is key to economic development through quality work, based on the knowledge. Through education man can overcome the limitations become a factor in achieving sustainable economic and social development.

All these are matters known and collected in this manner by any person, regardless of culture or social position. Differences of perception produces dichotomy education - formal education curriculum when placed variable. For example, analysis of curriculum at secondary school level in Romania, by comparison with standards of professional training (SPP) and items applying the graduates, the analyst creates an inconsistent picture or image

${ }^{1}$ http://ro.wikipedia.org/wiki/Educație 
of cardiograme a severe heart disease. This image crisis is shaped, mainly discordanțele of freedom of design, strong emphasis placed on creativity and modern methods of education offered by the SPP's criteria for promotion and graduation examination claiming, among other inaccuracies and a fantastic memory of graduates, to be able to reproduce the whole phrases of alternative textbooks.

Immanuel Kant ${ }^{2}$, says that a principle of education, which need to consider especially those charged with developing education programs is that the, "children should be educated not according to the present state but the best possible future state of the human genus, ie the idea that humanity and its entire mission.

Kant's conception of education, developed two centuries ago, is as valid today as then. The company went through profound transformations at that time was caused by industrialization. Today the situation is similar: before humanity opens a new horizon, a new bear Galactica "to development. Economic and social development can not be seen, analyzed and projected, but only in the context provided by global knowledge society, new media and education industries.

Unfortunately, the concepts of globalization, new economy and knowledge-based society, used so often in recent years have led to decipher but the mitadinage them. Romanian School, at least, they understood the only computer that can save us, that this machine is a kind of panacea that can address including lack of vision and preparation of school manager Therefore, perhaps, are born increasingly more questions about the position where we are, at this time, the existential focus: What is the role of education in the current circumstances? How can formal education to keep pace with new industry? What is the socio-professional profile of the graduate?

Principles of pedagogy and educational management, subject to official documents and literature, have undergone profound transformations over time. Demanding the same phrases, the same messages constitute the real locks of the mind when the subject is the formal. We are talking thus about the objectives, powers, the correlation between economic development and accumulation of knowledge, socio-professional profile of graduates in the new economy and knowledge society, importance of new media, etc.. Moreover, there are increasingly more voices that speak of efficiency and profitability, almost all heart estompând educational phenomenon for a society, role of formal education in shaping and polishing personalities, individuals regarded as 'particles' of a social system.

For example submit to the following issue: As a member of the European Union, Romania has to align the Community policy in education. Romania to the European Commission's recommendations on January 28, 2009, seeks swift implementation of structural reforms under the Lisbon Strategy, to ensure economic competitiveness based on high productivity, innovation and knowledge ${ }^{3}$.

Lisbon Strategy, sets out objectives and action plan on economic and social policies at European level: in the period 2010-2020, the European economy will become the most competitive and dynamic economy in the world, based on knowledge, capable of sustainable economic growth, generating new jobs and characterized by greater social cohesion ${ }^{4}$.

Objectives of education and training, according to the Lisbon Declaration ${ }^{5}$, are:

- increase the quality and efficiency of education and training in the European Union;

- facilitating access for all to education and training;

- education and training open to the world.

Beyond these objectives, which are not unusual, however, must admit that globalization and competitiveness, structural disruption of the labor market have increased functional gap

\footnotetext{
${ }^{2}$ Kant Immanuel - Despre pedagogie, Ed. Paideia, Bucureşti, 2002, p. 21

${ }^{3}$ www.edu.ro

${ }^{4}$ http://revistacalitateavietii.ro/2009/CV-1-2-2009/13.pdf Stoica Laura Gabriela - Accesul la educația continuă. Factor generator de inovație socială p. 122-129, accesat ianuarie 2010

${ }^{5}$ idem $^{4}$
} 
between education and other social sectors, creating new challenges for contemporary education.

You must also admit that the growing interdependence of national economies-globalization not only has economic dimensions ${ }^{6}$, but also political, cultural, educational, religious, etc.. This requires a reassessment of actions to increase the adaptability of the individual to the environment. Meanwhile, the attributes that characterize today's social system would not have been possible without the intervention of education, especially formal education. In other words, we are witnessing the necessary objective and consistent relationship between the two phenomena: the cause and effect. The phenomenon known issue - education, social change has led, which is no more than effect. This has become concerned for changes required by new circumstances - new economy.

In the present context created by the new economy, educational system bears a heavy responsibility: to create personalities mature, responsible, open knowledge and intercunoaşterii able to - and take risks and initiatives in all areas of socio-cultural activity ${ }^{7}$.

For this reason the view of Pierre Moeglin admit that, school is once again in crisis "8. Once again it is not the first time the organization mandated with training individuals as social subjects, is in crisis. In the $60 \mathrm{~s}$ of the last century there was a strong inadaptation school to real life problems and then imposed by society. That period was marked by a 'global crisis of education ". Philip Combs ${ }^{9}$ noted in this regard that there is a set of functional differences between education and other subsystems of society:

- In terms of quality education is found that the offer is too low in relation to the application;

- Social needs as human resources are not satisfied with the educational product;

- Methods and educational programs are tailored to the needs of society;

- Dynamic companies against inertia current organizational structure of education systems.

Educational systems worldwide are tested and are subjects of research for finding solutions to end the crisis. Thus, the U.S. is looking, the teacher perfect 'and' ideal school ', European Community countries develop new standards of performance and new methods of performance evaluation based on cost-benefit through the process of benefits quality. These concerns intensified in the formal education believe that there are only confirm the idea of crisis.

\section{Immunodeficiency educational management}

In order to establish a diagnosis of educational management, natural is to do the deciphering concepts being operated and the context in which the process takes place.

Theoretically things is as follows:

- opinion almost unanimously accepted in the literature is that economic and social transformations imposed by the following company will undoubtedly lead to changes in leadership styles at all levels.

- The information revolution, which mankind lives today requires new approaches to science management. They are particularly necessary in the educational system, the more apparent that here is formed members of society in general and labor required in the new economy, in particular.

- One of the directions, declared as a priority in education reform in Romania, aims decentralization process, the redistribution of responsibilities, decision-making authority, accountability and resources from central level to the local level, creating an organized education system, given and financed by European regulations. This requires commitment, accountability, vision and strategic thinking, skills and management, that a new type of

\footnotetext{
${ }^{6}$ Antonesei Liviu - Polis şi Paideia, Ed. Polirom, Iaşi, 2005, p. 22

${ }^{7}$ idem ${ }^{6}$

${ }^{8}$ Moeglin Pierre coord. - Industriile educației şi noile media, Ed. Polirom Iaşi, 2003, p. 177

${ }^{9} \mathrm{http}: / /$ www.avsp.ro/_lisabona.php
} 
manager ${ }^{10}$. The manager must not only vision but also the ability to attract, to combine and coordinate all resources necessary to conduct such a process.

- Management, that any man with the exponent requires a set of rules and principles needed to manage resources to achieve predetermined objectives.

Educational management enjoys attention increasingly higher current professional literature. Thus, management education has been defined by experts in the field, in many ways. Educational management and are given different understanding, being considered theory and practice, science and art design, organization, coordination, evaluation, features educational activities.

I Jinga ${ }^{11}$ considers, for example, that management education can be defined as science and art of preparing human resources, to train its staff, according to some finality accepted individual and society.

S. Cristea points ${ }^{12}$ that management education, psychological activity is based on three characteristics:

- Management of the primary system (holistic approach to all elements of education and specific applications of management functions at various levels);

- Management of type flying (the best use of educational resources education system, the management functions: planning, organizing, coordinating, monitoring);

- Strategic (future innovative development of the system at different levels of organization).

Educational management shows a certain mentality, their own way, but an art of management, the training resources, organization elements, which corresponds to the consideration that education is also science and art.

Regarding immunodeficiency management of school education, we can say that the three concepts - immunodeficiency, management and education - have a strong axiological load. They either analyzed separately or together are functions of several variables: economic and social context, existing values and promoted in society, economic and social policies in general and educational policies, in particular, etc..

From a health perspective is the reduction of congenital or acquired immunodeficiency state of immunity of the body. When immunodeficiency is marked and durable, it makes the patient very sensitive to opportunistic infections (caused by normally harmless germs and affecting only the bodies weak defense means) $)^{13}$.

Immunodeficiency educational management of school education, could translate his lack of response to 'germs' freed from the economic, political and social, which deeply affected him, precisely because it was not 'vaccine' against change in time.

Immunodeficiency educational management at the level of school education, not only evident in Romania. This issue affects all countries. It is a disease that disturbs all school systems in the postindustrial era of globalization.

One thing we can say with full responsibility: the rapidity of events do not allow the establishment of long-term objectives in education. It was conducive to the adoption of a management change, capable of effective decision.

Obviously we will not reinvent the wheel and we can not be possessors of miraculous solutions for management education in Romania, but we can emphasize certain aspects easy observation and the uninitiated in a field:

- The literature abounds in deciphering the concepts, the establishment of typologies, the hierarchy and sequence of steps, which are intended miraculous solutions to management in

\footnotetext{
${ }^{10}$ Gherman Liliana, Pănoiu Laura - Managementul resurselor umane, Ed. Ind. Economică, Piteşti, 2006, p. 10

${ }^{11}$ Jinga Ioan - Educaţia şi viața cotidiană, Ed. Didactică şi pedagogică, R.A. Bucureşti, 2005, p. 26

${ }^{12}$ Cristea Sorin, Pedagogie generală. Managementul educației, Ed. Didactică şi Pedagogică, Bucureşti, 1996

${ }^{13}$ http://www.sfatulmedicului.ro/dictionar-medical/imunodeficienta_3871
} 
general. Functions and management principles are taken, analyzed, processed, completed and adapted to various fields.

- For 20 years we are witnessing a 'reform' in education perpetual, worldwide. In Romania, reform is taking the models adopted in different countries of the world and endless discussions on quality, efficiency and performance in education.

- In terms of organization and coordination, education in Romania mangementul not have much to organize and coordinate. Unless staff working in the field (and whose analysis we do not now), other resources are lacking or are insufficient or are outdated.

- Appearance of organization and coordination may be similar to that existing in an economic organization, the primary objective of management is the organization to become a leader on the market without prior analysis of competition, held by the force (in terms of posse

Such a scenario is possible for the education system in Romania, which adoptâptând objectives and strategies to achieve them by different systems, without having the necessary resources to be 'removed from the market "in the end? Why not? While education is approached as an economic activity so long as it is brought down on any activities which discusses services, providers and beneficiaries about education, why not?

Suppose that the idea of turning to formal education in a low activity level of service provision is universally accepted. Suppose that supported the idea plusvalorii efficiency and education. In this case the starting point in setting goals are not need to analyze the context in which formal education is reported? Are discussed more beneficial education - social and economic system - but the curriculum is adopted in accordance with the beneficiary? What should disclose an analysis of the labor market in Romania and beyond?

It bears numerous discussions around the idea of skills training to education, so that at the end of the training process can be integrated into society, be able to carry out an activity to add value to the company. But do not discuss private corporate training request educabililor.

These issues, among other things could be the questions that should be sought answers. It could be a start in finding ways to improve educational management immunodeficiency.

Measures taken to date, important measures, as well as the goals and strategies are not likely to provide an improvement in terms of education management at undergraduate level. Multiplication of the tasks listed under 'job description' of teacher education, the establishment of the profile, the ideal teacher, high standards, which it must achieve, not to be one managemnetul educational quality and the system is performing.

Following implementation of Teachers surveys (questionnaires were distributed to a total of 150 teachers) working in four high schools in the central and south-eastern Romania, schools with different profiles, we obtained the following results on the preparedness of management if the decentralization process of school education:

- $78 \%$ expressed disagreement on decentralization, while only $22 \%$ were in favor of it;

- $64 \%$ said that the management of schools is totally unprepared to take over the duties of governor factor, $26 \%$ responded that management is prepared for this purpose only at a rate of below $50 \%, 6 \%$ said that management is prepared to this effect of $50 \%$ and $4 \%$ said that management is prepared in $100 \%$ in this respect;

- 56\% said that the performance or lack of performance of educational institution in which they operate is due to management, $44 \%$ responded that management has no interference in this regard;

- $46 \%$ said that the influence of organizational climate on performance is evident at $100 \%$, $32 \%$ said they exercised influence of $50 \%, 16 \%$ - less than $50 \%, 6 \%$ - not contribute to organizational climate obtain performance;

- $76 \%$ said that the organizational climate is the responsibility of the institution management, $24 \%$ said the responsibility in this regard is not management.

Conclusions drawn from the application of these questionnaires are:

- Decentralization is perceived by teachers as a measure that will produce negative effects on education; 
- Resistance to change, this time is justified by the lack of a quality management both at school level and at local institutions;

- No one ready to take over management duties imposed by statute governor factor;

- In the institutions currently unable to prove management with respect to ensuring organizational climate conducive to initiate a process of such complexity as the educational process.

\section{Decision effective - method of combating immunodeficiency management of pre-university education?}

The decision is a deliberate act, involving rational choice of possible solutions of the problems that considered optimal, with the intention of the desired effect.

Decision of the Standing accompanying management process, materialized ideas, intentions or projects. The decision is the response to a specific problem and is a form of social validation of an action, through the movement of resururselor human, material and money ${ }^{14}$.

In explaining the concept of decision, given the literature, we can deduce its main characteristics: $:^{15}$

- is a core business process management;

- is a process of harmonization of goals with resources;

- expresses the conceptualization of objectives and concepts to solve the conscious targeting of activities, relations, methodology;

- lead to psychosocial factors in solving cases by overcoming contradictions.

Decision effective means in fact the whole process done in three stages:

- preparation of the decision;

- the decision;

- Implementing the decision.

A process preceding the decision, in management education, is the performance evaluation. The information provided by performance measurement, enable an analysis of the facts in the issue of assumptions, which may be, or not to be solutions to problems indicated by the analysis. Checking assumptions / opinions from the implementation decision is made, continuing to check / control the way in which the decision applies and ending with evaluation of effects.

Decision effective, requires first a governor / liability factor effectively. It is logical that an organization's effectiveness, its ability to function and, in current circumstances created by the new economy, even survival, depend on the effectiveness of its members, especially the effectiveness of management at all levels.

The ability to be effective decision-maker is of paramount importance, in general, but the issue of growing importance particularly because the decision precedes, accompanies and follows the performance review process. Approached from this perspective, the effectiveness of the decision may be vital to the organization.

The effectiveness of the decision may be limited, in general, the following prejudice and barriers: ${ }^{16}$

- decision-maker believes that he is able to identify all the alternatives and consequences of each alternative;

- decision-maker can detach the problem;

- decision-maker believes that it has all relevant information;

- decision-maker believes that he is able to choose the best solution;

- Inadequate identification problem;

\footnotetext{
${ }^{14}$ Puiu Alexandru, Management, Ed. Independența Economică, Piteşti, 2004, p. 207

15 Tudorică Roxana, Managementul educației în context european, Ed. Meronia, Bucureşti, 2007, p. 234

${ }^{16} \operatorname{Idem}^{15}$, p. 235
} 


\section{Studies and Scientific Researches - Economic Edition, no. 15, 2010}

- There is a limited perspective during the phases of creation and exploration of decision making;

- inability to hand machines various types of information simultaneously;

- inability to think logically and methodically;

- lack of creativity;

- superficial analysis of the causes;

- lack of standards;

- indecision;

- incorrect dimensioning solutions.

Knowledge of these prejudices and barriers are of particular importance for improving decision making, especially in pre-university educational organizations, which decision shall be taken at the top and top-down effect. Therefore, we consider relevant, in effect, according to Peter Drucker's about effective decision.

Effective management, having the capacity to allow the adoption of effective decisions, we believe that is posed by Drucker. ${ }^{17}$

Thus, effective decision-maker:

- starts from opinions / hypotheses unverified

- trying to find out what really brings awareness test

- wonder which is the criterion of relevance

- consider the traditional method of measuring incorrect

- seek feedback before a decision on land

- take risks in finding appropriate methods demăsurare

- not decide if there is disagreement between the views

- Opposition sees the middle that allows it to consider alternatives

Decision-making, as we noted, requires real research. Makers effective, off-again, as we used, the facts and the traditional measurement methods, which Drucker deemed obsolete and should not require a decision, but would be sufficient simply to adapt. Appropriate measurement method can not be found only on the ground, and its adoption involves taking risks because, let's not forget that it starts from the hypothesis, therefore they are not validated by practice.

Effective decision based on conflicting opinions which are the main suppliers of alternatives. An effective governor must see the opponents of his opinion means which allows to consider alternatives, so it is important that decision-makers to deal with understanding the phenomenon and to assume responsibility for communication, but is concerned about the appearance of justice award. In this way you can avoid, reduce or even solve some state pressure, which could inhibit creativity, imagination, much needed educational process.

\section{References:}

1. Antonesei Liviu - Polis and Paideia, Polirom, Iasi, 2005

2. Cristea Sorin - General Education. Management education, Teaching and Pedagogical, Bucharest, 1996

3. Peter F. Drucker - Post-capitalist society, Image Publishing, 1999

4. Peter F. Drucker - Managing the Future, Asaba, Bucharest 2004

5. Peter F. Drucker - About Decision and effectiveness, Meteor Press, Bucharest, 2007

6. Ghergut Alois - General management and strategic education, Polirom Iasi, 2007

7. Gherman Liliana, Panoiu Laura - Human Resources Management, Economic Ind., Pitesti, 2006

8. Jinga John - Education and daily life, Teaching and pedagogical, RA Bucharest, 2005

9. Immanuel Kant - Pedagogy, Paideia Publishing House, Bucharest, 2002

10. Moeglin Pierre Coordinator - Education and new media industries, Polirom, Iasi, 2003

11. Puiu Alexandru - Management, Economic Independence, Pitesti, 2004

${ }^{17}$ Drucker F. Peter, Despre decizie şi eficacitate, Ed. Meteor Press, Bucureşti, 2007, p. 143-155 


\section{Studies and Scientific Researches - Economic Edition, no. 15, 2010}

12. Tudorici Roxana - Management Education in the European context, Meronia, Bucharest, 2007

13.http://www.avsp.ro/_lisabona.php

14.www.edu.ro

15.http://ro.wikipedia.org/wiki/Educație

$16 \mathrm{http}: / /$ revistacalitateavietii.ro/2009/CV-1-2-2009/13.pdf Stoica Laura Gabriela, Access to lifelong

learning. Elements of social innovation, p. 122-129, accesed January 2010 